\title{
International Diversification, Product Strategy, And Firm Value: Evidence From Korea
}

Donseung Choi, Ph.D. Candidate, Sogang University, South Korea Eunho Cho, Ph.D. Candidate, Sogang University, South Korea

\begin{abstract}
Existing studies showed inconsistent results for the relationship between international diversification (ID) and firm value. Thus, we primarily examine whether each MNC's product strategy moderates the relationship between ID and firm value. The results show that MNCs' product strategy moderates the relationship between ID and firm value as measured by Tobin's $Q$. Specifically, a positive relationship exists between ID and firm value in the firm group pursuing a cost leadership strategy, whereas a negative relationship exists between the same variables in the firm group pursuing a differentiation strategy, suggesting that the "strategic fit" between product strategy and ID is likely an important factor in the relationship between ID and firm value. Our results remain robust after conducting sensitivity analyses using the price-to-book value (PBR) ratio and individual components of composite ID measures. Accordingly, we conclude that a cost leadership strategy of Korean MNCs is more likely to have a competitive advantage in a foreign market than a differentiation strategy. This study primarily contributes to the literature on ID in that it provides the first evidence on the relationship between ID and firm value that takes into account an MNC's product strategy using the "strategic fit" perspective.
\end{abstract}

Keywords: International Diversification; Firm Value; Product Strategy; Korean MNCs

\section{INTRODUCTION}

$n$ this study, we empirically investigate whether Korean multinational corporations' (MNCs) product
strategy affects the relationship between international diversification (ID) and firm value. In other
words, we examine whether MNCs' product strategy moderates the relationship between ID and firm value. The world economy becomes more integrated by the global activity of MNCs. Although active movements of goods and services facilitate a more integrated world economy, these movements are actually being disturbed by a variety of trade barriers among nations. Thus, MNCs have been attempting to internationally diversify their trade channels and production lines to extend foreign market opportunities and reduce production costs. However, none of these efforts appear to warrant successful results to improve a firm's business performance. Thus, we raise a primary question: Indeed, what is the main factor for making MNCs' ID successful with respect to the relationship between ID and firm value? Does the strategic $f_{i t}{ }^{1}$ perspective play an important role in the relationship between ID and firm value?

Researchers have made efforts to draw definite conclusions regarding the relationship between ID and firm value throughout the decades. However, the theoretical arguments and empirical evidence on the relationship have been inconsistent (Lewellen, 1971; Myerson, 1982; Jensen, 1986; Berger \& Ofek, 1995; Fauver et al., 2004; Dos Santos et al., 2008). Actually, ID has potential benefits and costs to firm value. The benefits of ID include economies of scale and scope, diversifying risk, acquisition of scarce resources, and lower tax costs. In contrast, the costs of ID are related to agency costs, power struggles between departments, and transaction costs. Because of

\footnotetext{
${ }^{1}$ Strategic fit is a situation in which the organization's resources and capabilities are efficiently aligned with the opportunities and threats that it
} faces (Andrews, 1980). 
these conflicting arguments, clearly predicting the direction of the relationship between ID and firm value is still difficult.

Despite prior studies' contribution to the literature on ID and firm value, these studies seem to have several limitations. First, most prior studies overlooked the role of other strategic factors besides ID. On the basis of the concept of "fit" (Miles \& Snow, 1984; Slater \& Olson, 2000; Zajac et al., 2000), the "fit" between ID and other strategies should be considered because "fit" is highly likely to influence firm performance and make a firm successful. Thus, we need to consider other strategic factors in this study, such as product strategy. Second, they also ignored the environmental context in which MNCs were closely involved, although the "fit" between strategy choice and environmental context is important to improving firm performance (Katsikeas et al., 2006). That is, the particular environmental context influences the success or failure of MNCs' ID strategy. As such, the relationship between ID and firm value must be examined by considering the "fit" between the environmental context of ID and product strategy. Finally, prior empirical studies generally focused on firms in the United States (Garrod \& Rees, 1998). Some prior studies used data on European MNCs, such as those from the United Kingdom, Germany, and other European Union countries. Accordingly, using Korean MNC data, we extend prior studies to determine whether a different environmental context influences the relationship between ID and firm value.

We use a sample of 345 firm-year observations from Korean listed manufacturing MNCs. The level of ID is measured using a composite score from Strike et al. (2006). Firm value is measured using Tobin's Q following Chung and Pruitt (1994). The product strategy, differentiation, and cost leadership strategy are measured using R\&D and advertisement intensity, which is consistent with Hambrick (1983).

The results are as follows. First, we do not find a significant relationship between ID and firm value. Second and more importantly, we observe that a MNC's product strategy moderates the relationship between ID and firm value. Specifically, a positive relationship exists between two variables in the firm group pursuing a cost leadership strategy; whereas a negative relationship exists between two variables in the firm group pursuing a differentiation strategy. These relationships suggest that the "fit" between product strategy and ID is likely to be an important factor in the relationship between ID and firm value. Our results remain robust after conducting sensitivity analyses using individual components of ID composite measures and the price-to-book value (PBR) ratio. Consequently, we conclude that a cost leadership strategy of Korean MNCs is more likely to have a competitive advantage in the foreign market than a differentiation strategy.

This study contributes to the literature on the relationship between ID and firm value in several ways. First, using the strategic fit perspective as a platform for our study, we provide the first empirical evidence that the "fit" between MNCs' product strategy and ID strategy must be considered in the decision-making process if MNCs' ID strategy is to enhance firm value. Second, the unique national context should be taken into account to examine the relationship between ID and firm value because the "fit" between a firm's strategy and environmental context is also important to achieve better performance (Katsikeas et al., 2006). Third, in this study, we use composite ID measures and three individual components, ${ }^{2}$ leading to comprehensive studies on the effect of ID level on firm value. Finally, using a sample of Korean listed manufacturing MNCs, we extend the prior literature that mostly concentrated on U.S. or EU firms.

The remainder of this paper proceeds as follows. In Section 2, we review the prior literature on ID and firm value and develop hypotheses. Section 3 describes the data and sample selection, measurement of the selected variables, and the research regression model. Section 4 discusses the empirical results. Finally, we summarize and conclude in Section 5.

\footnotetext{
${ }^{2}$ Three components are overseas sales percentage of total sales, number of foreign subsidiaries, and number of countries in which MNCs have entered.
} 


\section{LITERATURE REVIEW AND HYPOTHESIS DEVELOPMENT}

Figure 1 shows the research framework. Specifically, this study empirically examines whether ID is associated with firm value (H1) and, more importantly, whether a MNC's product strategy moderates the relationship between ID and firm value (H2).

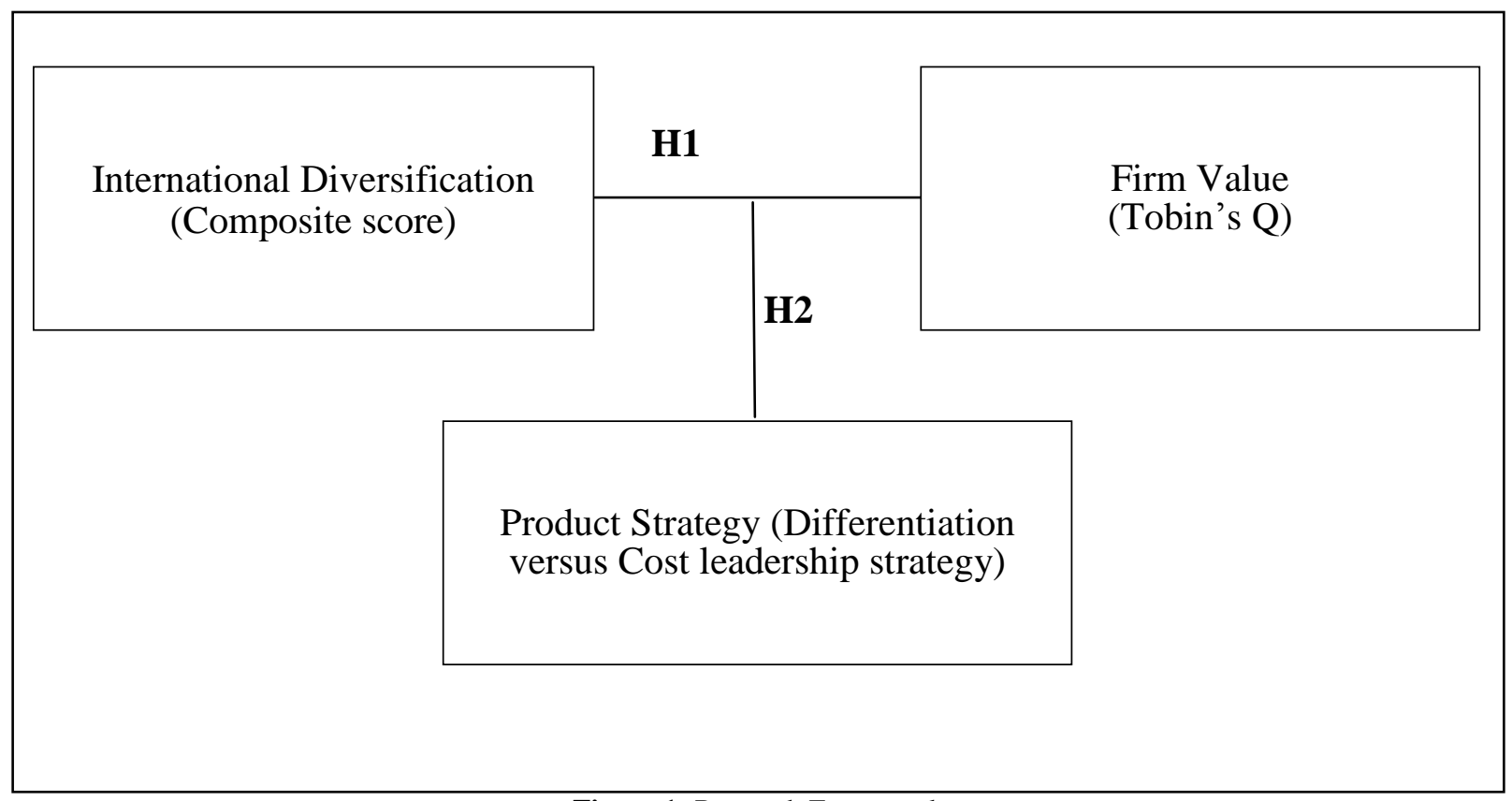

Figure 1: Research Framework

Hitt et al. (1997) defined ID as expansion across the borders of global regions and countries into different geographic locations or markets. Practitioners in MNCs have attempted to reinforce their own competitiveness and explore market opportunities by entering the global market. Thus, ID has been a key strategic topic for international business scholars for a long time. Prior studies emphasized the various benefits of ID (Rugman, 1979; Kogut, 1985; Caves, 1996). Caves (1996) argued that ID, as a means of geographic diversification, provides MNCs with benefits from realizing economies of scale and scope. ID also has a comparative advantage by securing a location-specific advantage to obtain lower costs of production factors (Kogut, 1985). In contrast, more recently, researchers noticed the costs of ID (Jensen, 1986; Stulz, 1990; Gomes \& Ramaswamy, 1999). The background of these arguments is primarily based on transaction or agency cost theory. Because ID makes it difficult for MNCs to manage widespread firms located in different cultural environments, MNCs' managerial costs eventually increase (Gomes \& Ramaswamy, 1999). Stulz (1990) also argued that managers in diversified firms invest too much in some low-profitmaking projects.

Using these theoretical arguments regarding the benefits and costs of ID, prior studies provided that ID has both value-enhancing and -reducing effects (Saudagaran, 2002). Lewellen (1971) argued that diversified firms are able to have greater debt capacity and reduce the tax burden from combining businesses. The resource-based view (Barney, 1991) and core competence theory (Prahalad \& Hamel, 1990) assert that multinational enterprises have a competitive advantage in achieving economies of scope by allocating the existing "rent-yielding" resources (Tallman \& Li, 1996). MNCs also show good performance from the benefits from economy of scale and scope (Hitt et al., 1997). These effects enhance firm value through the achievement of better performance.

However, contradictory arguments exist that emphasize the costs of ID. These arguments are mostly based on transaction costs (Lu \& Beamish, 2004). Jensen (1986) noted the inefficiency of ID because diversified firms are likely to invest more in negative net present value (NPV) projects than stand-alone companies. Moreover, the models presented by Meyer et al. (1992) and Rajan et al. (2000) showed that senior managers of MNCs exert their 
power to gain more assets under their own control, which leads to reducing firm value by making operations inefficient or triggering power struggles between departments.

The empirical results regarding the value effects of ID are also inconsistent. Using UK firm-level data, Garrod and Rees (1998) documented that MNCs have higher earnings and net assets than domestic firms. However, Berger and Ofek (1995) reported that firms' actual values had $13 \%$ to $15 \%$ lower average estimates than the sum of the stand-alone values from 1986 to 1991 because of diversification. This result implies that value loss could be caused by overinvestment and cross-subsidization, although the tax benefits of diversification may reduce the extent of the loss. Denis et al. (2002) used a sample of 44,288 U.S. firm-years between 1984 and 1997 and found that global diversification leads to valuation discounts, suggesting that the costs of ID are larger than its benefits. Waldron (2006) reported that greater market diversification is likely to cause a higher cost of capital, thereby resulting in a decreasing market value. Fauver et al. (2004) provided that U.S. MNCs' ID creates value reducing effects relative to domestic firms, although no impact of ID occurred on the firm value of German and UK firms. In contrast, Dos Santos et al. (2008) showed that ID has no value reducing effect by examining cross-border mergers and acquisitions of U.S. acquirers during 1990-1999.

On the basis of the existing studies, we find mixed results for the relationship between ID and firm value. However, the majority of these existing papers empirically reported inconsistent or negative results regarding the value effects of ID. Thus, we propose the following hypothesis (H1).

Hypothesis 1: A negative relationship exists between ID and firm value.

Previous studies on ID and firm value primarily focused on the direct relationship between ID and firm value based on the benefits and costs of ID. However, Naman and Slevin (1993) reported that "fit" is a crucial construct as a factor for a firm's success. ${ }^{3}$ Accordingly, we expect that the " $f i t$ " between a MNC's product strategy and ID could play an important role in the relationship between ID and firm value. In other words, product strategy may be an important strategic factor when MNCs implement an ID strategy because a MNC's product strategy may influence a firm's success through positioning in the industry in which the firm belongs.

Thus, to investigate the product strategy with a better fit with ID strategy by taking into account the competitive advantage of Korean firms in foreign markets, this study classifies all samples into two product strategies: differentiation and cost leadership. The objective of a differentiation strategy is to create uniquely attractive products through a reputation for quality and a good brand image. To achieve this aim, firms generally make higher investments in research and development (R\&D) and advertising relative to sales revenue than those pursuing a cost leadership strategy. Thus, firms pursuing a differentiation strategy may have a weaker competitive advantage with respect to price in foreign markets given high expenditures on R\&D and advertisement, which are ultimately added to product price. Hence, MNCs' proper implementation of a product differentiation strategy considering the environmental context of their ID gives them better bargaining power with consumers because consumers' preferences are more likely to be high (Takeuchi \& Porter, 1986). A differentiation strategy may also be successful by offering consumers who are less sensitive to product price but more sensitive to quality and uniqueness (Helsen et al., 1993).

In contrast, a cost leadership strategy aims to supply goods and services at a lower price than competitors do. Thus, if firms appropriately implement a cost leadership strategy, MNCs' ID could be successful by reducing production costs through vigorous cost minimization management. On the basis of these arguments, we expect that MNCs' product strategy is likely to affect the relationship between ID and firm value. Accordingly, we establish the following hypothesis (H2).

Hypothesis 2: MNCs' product strategy moderates the relationship between ID and firm value.

\footnotetext{
${ }^{3}$ Similarly, Miles and Snow (1984), Porter (1996), Slater and Olson (2000), and Zajac et al. (2000) suggested that a fit between organizational properties and strategic choice is important for a successful business because it offers superior performance to firms.
} 


\section{RESEARCH DESIGN}

\section{Data And Sample Selection}

We collect our sample from KISVALUE, which is provided by one of the largest financial data providers in Korea, and TS2000, which is provided by the Korea Listed Companies Association. We restrict our sample to 345 Korean listed manufacturing MNCs' firm-year observations with at least one foreign affiliate. The ID strategy of Korean MNCs is most pronounced in the manufacturing sector, which accounts for approximately 70 percent of the entire industry. Moreover, the manufacturing industry is considered a proper sample group in that the product strategy we use in this study is more associated with the manufacturing industry than other industries. In addition, the manufacturing industry is more likely related to exporting products and expanding to overseas markets. Furthermore, each firm-year observation must have the available data necessary to calculate ID and control variables.

In contrast, Figure 2 shows how we divided all 554 samples into the two strategy groups employed in this study. More specifically, we use each firm's six-year average R\&D and advertisement intensity to select samples that capture high R\&D and high advertisement intensity (differentiation strategy group) and low R\&D and low advertisement intensity (cost leadership strategy group). Thus, we exclude mixed combinations of R\&D and advertisement intensity for 209 observations. Hence, the final sample includes 345 firm-year observations for the period 2005-2010.

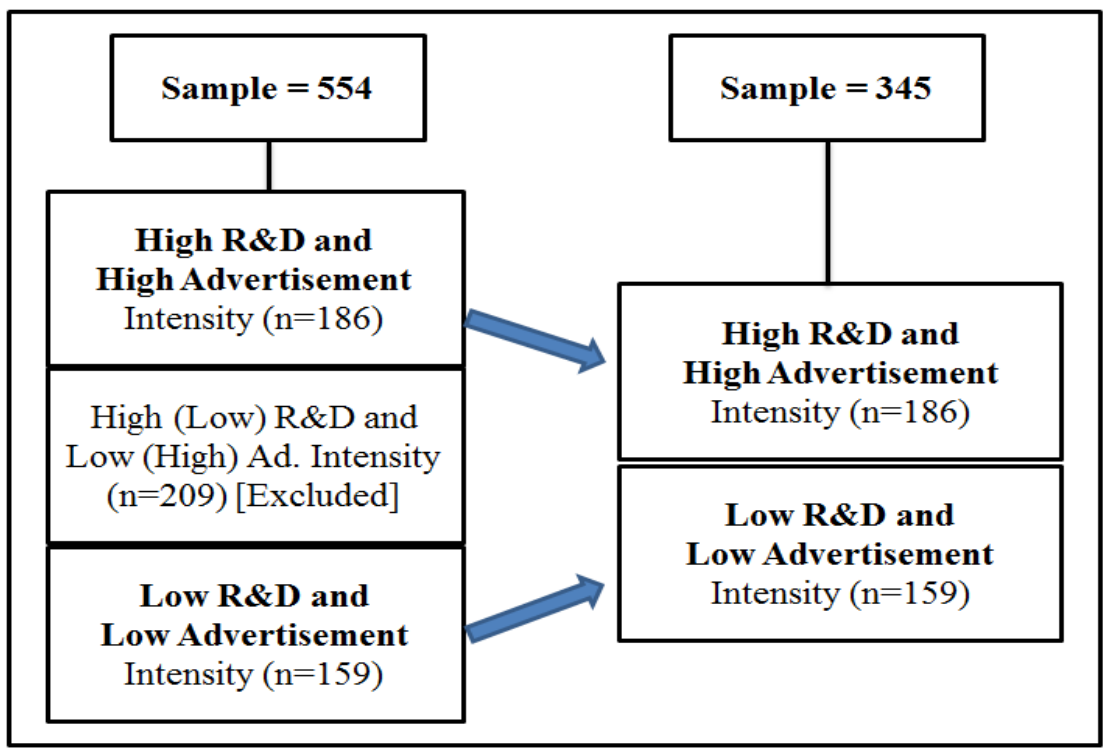

Figure 2: Method Of Dividing Samples Into Two Groups Excluding The Mixed One: Differentiation And Cost Strategy Groups

\section{Measurements Of Firm Value, ID, Moderating, And Control Variables}

As a dependent variable, we use $T O B I N Q$ to proxy firm value. As a primary independent variable of interest, we use $I N T L \_D I V$ to measure the level of ID. The $I N T L \_D I V * D U M \_D I F F$ variable represents our primary research interest to determine a moderating effect. We also include several control variables in the regression models.

Firm Value: TOBINQ

We use $T O B I N Q$ as the dependent variable to measure firm value, which is widely used and accepted as a measure of shareholders' wealth enhancement as a firm's goal (Lindenberg \& Ross, 1981; Akpinar et al., 2008; Choi et al., 2010; Lien \& Li, 2013). Tobin's Q is known as a robust indicator when researchers compare various 
firms because the ratio reflects the change in theoretically valued stock prices using the present value of long-term future cash flows, and is widely used for firm performance (Lien \& $\mathrm{Li}, 2013$ ). Tobin's Q is a proper measure for our study for the following reasons. First, in this study, we use the concepts of two types of strategies-product and ID - that may have a long-term effect (Mizik \& Jacobson, 2003, p. 67). Second, Tobin's Q is highly related to the stock price with which shareholders are mostly concerned. Hence, Tobin's Q is associated with shareholders' or firms' ultimate goal, which is shareholder value maximization. Accordingly, Tobin's Q is more appropriate than accounting performance measures such as return on assets (ROA) and return on equity (ROE) that are more closely related to past short-term performance.

\section{ID: INTL_DIV}

We follow Strike et al. (2006) to measure the level of ID, which includes both international depth and dispersion. International depth has two components: a firm's overseas sales percentage of total sales and the number of foreign subsidiaries (Eden et al., 2003). International dispersion is measured using the number of countries that MNCs have entered (Allen \& Pantzalis, 1996; Eden et al., 2003). Specifically, we determine the extent of ID using factor analysis and data on 1) foreign market penetration measured using export percentage of total sales and 2) foreign market presence measured using the number of foreign affiliates and countries. To obtain various perspectives of ID measures, we manually obtain data on affiliates of Korean-listed manufacturing MNCs from TS2000. We classify manufacturing firms using the country name included in foreign affiliates' company name. We standardize all three indicators before the factor analysis, and the eigenvalue of the unique factor is 2.03 . The Cronbach's alpha for the three indicators is 0.709 , indicating a proper level of reliability.

\section{Moderating Effect: INTL_DIV*DUM_DIFF}

To test the moderating effects of product strategy on the relationship between INTL_DIV and TOBINQ, we separate the entire sample into two firm groups, each pursuing a differentiation strategy and a cost leadership strategy, as suggested by Porter (1980), and that are represented by DIFF. We follow the methodology of Hambrick (1983), Hull and Rothenberg (2008), and McWilliams and Siegel (2000) to measure the differentiation and cost leadership strategies. For example, Hambrick (1983, p. 694) suggested that product innovation measured by product R\&D divided by sales revenues indicates differentiation, and that marketing expenditures measured by promotion expenses divided by sales revenues indicates differentiation. Our interactive variable is $I N T L \_D I V * D U M \_D I F F$ calculated as INTL_DIV times DUM_DIFF.

\section{Control Variables}

In this study, to avoid the problem of correlated omitted variables, we use several control variables that may affect the relationship between INTL_DIV and TOBINQ. A firm's characteristic variables included in this equation are firm size (SIZE), growth (GROWTH), leverage (LEVERAGE), profitability (PROFIT), business risks $(R I S K)$, and firm age (FIRM_AGE). In addition, industry and year dummy variables are included in the research model to control a firm's industry and year effects.

Firm size is employed in many empirical studies as a control variable (Shin \& Stulz, 1998). Black et al. (2006) and Demsetz and Lehn (1985) showed that firm size is negatively associated with firm value. However, if economies of scale exists, the larger firm size, the higher firm value. Additionally, a large firm is more likely to disclose more information about itself, thus, decreasing uncertainty about itself firm. A firm's growth rate is an important positive factor in the functioning of its stock price. Thus, a higher sales growth rate results in a higher firm value. We use the three-year average sales growth rates. In term of leverage, we use total liabilities divided by total assets (De, 1992). Leverage is also used as a control variable that affects a firm's value (De, 1992). If a firm's leverage is not high, interest expense can contribute to lowering its weighted average cost of capital because of tax deduction effects, thereby leading to a higher Tobin's Q. Profitability and business risk are included in this model to estimate market-based performance such as Tobin's Q (De, 1992; Kook \& Kang, 2011). We expect that profitability is positively associated, and risk is negatively associated, with firm value. Firm age is also frequently used in valuation studies on firms (Kim, 2009). Firms that are old are likely to be in a mature industry, leading to a restriction of their growth potential and a lower Tobin's Q. We use 15 industry dummy variables to control 16 KSIC 
(Korea Standard Industry Classification) two-digit industry characteristics. We also include five-year dummy variables to control for changes in economic conditions during the six years of this study (Lien \& Li, 2013).

\section{Multivariate Regression Equation}

To capture the relationship between INTL_DIV measured using the composite score and TOBINQ as a proxy for and measure of firm value, following the method of Chung and Pruitt (1994), we estimate the following multivariate regression equation (1).

$$
\begin{aligned}
\text { TOBINQ }_{i . t}= & \alpha_{0}+\alpha_{1} I N T L \_D I V_{i, t}+\alpha_{2} \text { DUM_DIFF }_{i, t}+\alpha_{3} I N T L_{-} D I V^{*} D U M_{-} D I F F_{i, t}+\alpha_{4} \text { SIZE }_{i, t}+\alpha_{5} \text { GROWTH }_{i, t} \\
& ++\alpha_{6} \text { LEVERAGE }_{i, t}+\alpha_{7} \text { PROFIT }_{i, t}+\alpha_{8} R_{\text {RISK }}+\alpha_{i, t}+\alpha_{9} F I R M_{-} A G E_{i, t}+\sum I N D_{i, t}+\sum Y E A R_{i, t}+\varepsilon_{i, t} \quad(1)
\end{aligned}
$$

\begin{tabular}{|c|c|}
\hline \multicolumn{2}{|l|}{ Dependent Variables } \\
\hline TOBINQ & $\begin{array}{l}=\text { (market value of common and preferred stock }+ \text { (current liabilities }- \text { current } \\
\text { assets })+ \text { long term debts) / book value of total assets. }\end{array}$ \\
\hline \multicolumn{2}{|l|}{ Variable of Interest } \\
\hline$I N T L \_D I V$ & $=$ standardized score combining three indicators using factor analysis; ${ }^{4}$ \\
\hline DUM_DIFF & $\begin{aligned} &= \text { dummy variable that equals } 1 \text { if firms pursue the differentiation strategy } \\
& \text { measured using R\&D and advertisement, following the methodology of } \\
& \text { Hambrick (1983), and } 0 \text { otherwise; and, }\end{aligned}$ \\
\hline$I N T L \_D I V * D U M \_D I F F$ & $=$ interaction term, measured as $I N T L \_D I V \times D U M \_D I F F$. \\
\hline \multicolumn{2}{|l|}{ Control Variables } \\
\hline SIZE & $=$ natural log of total asset; \\
\hline GROWTH & $=$ average sales growth rate for the past three years; \\
\hline LEVERAGE & $=$ total liability / total assets; \\
\hline PROFIT & $=$ EBITDA $/$ total assets; \\
\hline RISK & $=$ standard deviation of the past five years' EBITDA / total assets'; \\
\hline FIRM AGE & $=$ natural $\log$ of $(1+$ the number of years since the firm's establishment $)$; \\
\hline IND & $\begin{array}{l}=\text { industry dummy based on two-digit Korea standard industry classification } \\
\text { code; and, }\end{array}$ \\
\hline$Y E A R$ & $=$ year dummy. \\
\hline
\end{tabular}

where, for company $i$ in period $t$ :

\section{EMPIRICAL RESULTS}

\section{Descriptive Statistics And Correlation Analysis}

In Table 1, we report the descriptive statistics and Pearson correlations coefficients for selected variables. Table 1 shows a mean value of 0.622 for Tobin's Q (TOBINQ) and 0.133 for the level of ID (INTL_DIV), respectively. For the control variables, the mean value of firm size (SIZE) is US\$624 million. The mean values of sales growth rates (GROWTH) and profitability (PROFIT) are 12.2 percent and 9.4 percent, respectively, indicating that our sample firms realized, on average, good performance. Additionally, the mean value of leverage (LEVERAGE) is 42.2 percent, implying that the debt ratio or the leverage ratio is not that high and indicating that, on average, the capital structure of sample firms appears stable. The mean volatility of earnings (RISK) of the sample firms is 2.9 percent, showing a low level of earnings volatility. Lastly, we observe that the mean value of firm age since establishment (FIRM_AGE) is 36 years.

Table 1 also shows correlation coefficients for selected variables. TOBINQ is positively correlated with INTL_DIV and is positively (negatively) correlated with SIZE, LEVERAGE, PROFIT, and FIRM_AGE, as expected.

\footnotetext{
${ }^{4}$ Three indicators consist of foreign market penetration (export amount / total sales amount) and foreign market presence (number of foreign subsidiaries held by firms and total number of countries in which affiliates are located).

${ }^{5}$ EBITDA = Earnings before interests, taxes, depreciation, and amortization.
} 
We also find that the correlation coefficient between INTL_DIV and SIZE is 0.600 , indicating that these two variables may cause a multicollinearity problem in that the coefficient is slightly larger than 0.5 . However, the SIZE variable controlling a firm's characteristic is widely used in the research model to measure performance. Hence, we include firm size as a control variable. We perform the regression analysis and check the multicollinearity problem using VIF (variation inflation factors) with criteria of less than 10. As a result, we observe no material problems in our sample.

Table 1: Descriptive Statistics And Correlations Among Selected Variables

\begin{tabular}{|c|c|c|c|c|c|c|c|c|}
\hline & & Mean & Sd. & 1 & 2 & 3 & 4 & 5 \\
\hline 1. & $T O B I N Q$ & 0.622 & 0.617 & 1 & & & & \\
\hline 2. & $I N T L \_D I V$ & 0.133 & 1.239 & $0.276 * *$ & 1 & & & \\
\hline 3. & $D I F F$ & 0.539 & 0.499 & $0.264 * *$ & $0.256^{* *}$ & 1 & & \\
\hline 4. & $S I Z E$ & 27.256 & 1.440 & $0.374 * *$ & $0.600 * *$ & $0.159 * *$ & 1 & \\
\hline 5. & GROWTH & 0.122 & 0.217 & 0.061 & -0.02 & -0.016 & 0.041 & 1 \\
\hline 6. & LEVERAGE & 0.422 & 0.166 & $0.226 * *$ & $0.281 * *$ & 0.078 & $0.277 * *$ & 0.065 \\
\hline 7. & PROFIT & 0.094 & 0.054 & $0.461 * *$ & 0.072 & 0.057 & $0.149 * *$ & 0.087 \\
\hline 8. & RISK & 0.029 & 0.020 & $0.113 *$ & $0.106^{*}$ & -0.036 & 0.024 & 0.068 \\
\hline \multirow[t]{3}{*}{9.} & $F I R M \_A G E$ & 3.594 & 0.510 & $-0.373 * *$ & -0.073 & $-0.115^{*}$ & -0.056 & $-0.106^{*}$ \\
\hline & $\mathrm{N}$ & 345 & 345 & 345 & 345 & 345 & 345 & 345 \\
\hline & & Mean & Sd. & 6 & 7 & 8 & 9 & \\
\hline 6. & LEVERAGE & 0.422 & 0.166 & 1 & & & & \\
\hline 7. & PROFIT & 0.094 & 0.054 & 0.017 & 1 & & & \\
\hline 8. & RISK & 0.029 & 0.020 & -0.006 & $0.261 * *$ & 1 & & \\
\hline \multirow[t]{2}{*}{9.} & FIRM_AGE & 3.594 & 0.510 & $-0.170 * *$ & $-0.157 * *$ & $-0.131 *$ & 1 & \\
\hline & $\mathrm{N}$ & 345 & 345 & 345 & 345 & 345 & 345 & \\
\hline
\end{tabular}

Notes: The Pearson correlations are shown below the diagonal. * and ** indicate statistical significance at the 5 percent and 1 percent levels in a two-tailed test, respectively. Variables are defined in Appendix A.

\section{Results Of Regression Analyses}

In Table 2, we report the results of the regression analyses. The dependent variable used to measure firm value is TOBINQ. The independent variable of interest (H1) is INTL_DIV, which represents the level of ID. More importantly, the main variable of interest $(\mathbf{H 2})$ is $I N T L_{-} D I V^{*} D U M_{-} D I F F$. We find that the estimated coefficient is negative but insignificant $(-0.004$ (t-stat: -0.11$)$ ), which is inconsistent with, and does not support, our first hypothesis (H1). However, considering the prior studies' mixed results on the relationship between two variables, observing no significant relationship is not surprising.

In contrast, consistent with our hypothesis $(\mathbf{H 2})$ that product strategy moderates the relationship between $I N T L \_D I V$ and $T O B I N Q$, we observe a negative coefficient and significant $\mathrm{p}$-value $(-0.306(\mathrm{p}<0.01))$. This result suggests that product strategy seems to influence the relationship between ID and firm value, and that the cost leadership product strategy is a better strategic fit with Korean MNCs' ID than the differentiation strategy. Interestingly, we confirm this result by running two separate regressions after dividing the entire sample into two groups, resulting in a positive and significant relationship between INTL_DIV and TOBINQ in the cost leadership strategy group but a negative and insignificant relationship in the differentiation strategy group.

This result suggests that a cost leadership product strategy is more likely to realize "fit" with the environmental context of Korean MNCs' ID. That is, Korean MNCs have a core competency in price competitive advantages: firms pursuing a cost leadership strategy are targeted rather than firms pursuing a differentiation strategy. In summary, these findings support the notion that " $f i t$ " is an important construct for firm success (Miles \& Snow, 1984; Naman \& Slevin, 1993; Porter, 1996).

This result is also interpreted as Korean MNCs' ID having a better fit with a cost leadership strategy in a foreign market, leading to a positive relationship between ID and firm value. The reasons are as follows. First, Korea's unique historical and environmental context influences the strategic success or failure of Korean MNCs. Traditionally, Korean manufacturing MNCs have enjoyed a competitive advantage from low production costs. Using cheap labor, Korean MNCs enhanced their competitive prices in the global market. Second, ID fitted or 
combined with a cost leadership strategy drives greater core competences to Korean MNCs in the foreign market than ID unfitted with a differentiation strategy because many MNCs moved production lines to East Asian countries for lower wages from the 1980 s to the 2000 s.

Turning to the control variables, in model 2, all of the coefficients for the SIZE, LEVERAGE, and PROFIT variables are positive and significant $(\mathrm{p}<0.01)$, indicating that larger firms, firms with higher leverage ratios, and profitable firms are more likely to have a positive effect on $T O B I N Q$, as predicted. Under a stable capital structure such as for our sample, a high leverage or debt ratio may help enhance firm value through tax deduction effects. In contrast, FIRM_AGE is negatively associated with TOBINQ, suggesting that older firms are more likely to negatively affect $T O B I N Q$. The difference between the market value of equity and the book value of equity is often larger in a growing industry than the maturity industries in which older firms frequently belong. Lastly, the adjusted $\mathrm{R}^{2}$ values are larger than 0.47 , indicating reasonable explanatory power.

Table 2: Multiple Regressions Of TOBINQ On INTL_DIV

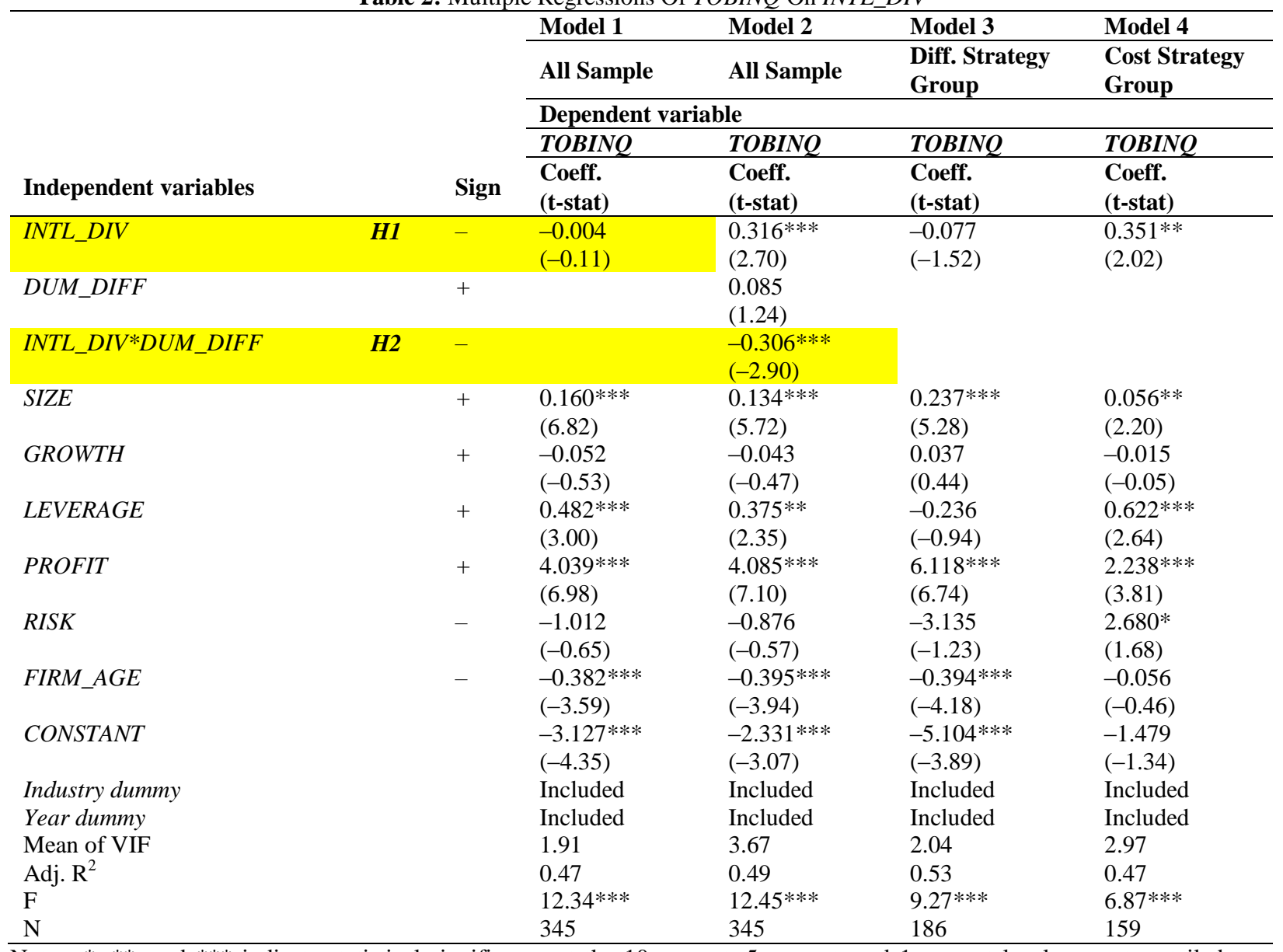

Notes: *,**, and $* * *$ indicate statistical significance at the 10 percent, 5 percent, and 1 percent levels on a two-tailed test, respectively. Variables are defined in Appendix A. All test statistics and significance levels are calculated on the basis of robust standard errors adjusted for heteroskedasticity at the firm and year levels.

\section{Robustness Tests}

To provide construct validity for INTL_DIV, we conduct robustness tests using three individual components and the INTL_DIV composite score as a dependent variable. As shown in Table 3, we observe that all of the coefficients of the interactive terms (ID_EXPORT*DUM_DIFF, ID_AFF*DUM_DIFF, and $\left.I D \_C O U N T^{*} D U M \_D I F F\right)$ in Panels $\mathrm{A}, \mathrm{B}$, and $\mathrm{C}$ are negative and significant $(\mathrm{p}<0.01)$, indicating that $I N T L \_D I V$ 
is widely affected by the respective individual components, providing construct validity for INTL_DIV and supporting the second hypothesis $(\mathbf{H 2})$. Further, we confirm that a positive relationship exists between INTL_DIV and $T O B I N Q$ in the cost leadership strategy group, whereas a negative relationship exists between two variables in the differentiation strategy group, thus supporting the second hypothesis (H2).

In addition, in Panel A, we find that ID_EXPORT is negatively and significantly associated with TOBINQ, whereas $I D \_A F F$ and ID_COUNT are negatively and insignificantly associated with TOBINQ. This result suggests the importance of the measurement issue on level of ID; if the researcher uses only the ID_EXPORT variable, the study may lead to different conclusions regarding the relationship between ID and firm value. In summary, in our robustness tests, we provide supporting evidence for the construct validity for the INTL_DIV variable, the proxy for ID level.

Table 3: Multiple Regressions Of TOBINQ On Individual Components Of INTL_DIV

\begin{tabular}{|c|c|c|c|c|c|c|}
\hline \multirow[b]{5}{*}{ Independent variables } & & & \multirow{2}{*}{$\begin{array}{l}\text { Model } 1 \\
\text { All Sample }\end{array}$} & \multirow{2}{*}{$\begin{array}{l}\text { Model } 2 \\
\text { All Sample }\end{array}$} & \multirow{2}{*}{$\begin{array}{l}\text { Model } 3 \\
\text { Diff. Strategy } \\
\text { Group }\end{array}$} & \multirow{2}{*}{$\begin{array}{l}\text { Model } 4 \\
\text { Cost Strategy } \\
\text { Group } \\
\end{array}$} \\
\hline & & & & & & \\
\hline & & & \multicolumn{4}{|c|}{ Dependent variable } \\
\hline & & & TOBINQ & TOBINQ & TOBINQ & TOBINQ \\
\hline & & & $\begin{array}{l}\text { Coeff. } \\
\text { (t-stat) }\end{array}$ & $\begin{array}{l}\text { Coeff. } \\
\text { (t-stat) }\end{array}$ & $\begin{array}{l}\text { Coeff. } \\
\text { (t-stat) }\end{array}$ & $\begin{array}{l}\text { Coeff. } \\
\text { (t-stat) }\end{array}$ \\
\hline \multicolumn{7}{|l|}{ Panel A: ID_EXPORT } \\
\hline$I D \_E X P O R T$ & H1 & - & $\begin{array}{l}-0.085 * * \\
(-2.36)\end{array}$ & $\begin{array}{l}0.029 \\
(0.79)\end{array}$ & $\begin{array}{l}-0.207 * * * \\
(-4.03)\end{array}$ & $\begin{array}{l}0.109 * * * \\
(2.76)\end{array}$ \\
\hline$D U M \_D I F F$ & & + & & $\begin{array}{l}0.084 \\
(1.34)\end{array}$ & & \\
\hline $\begin{array}{l}I D \_E X P O R T * D U M \_D I F \\
F\end{array}$ & $\mathrm{H} 2$ & - & & $\begin{array}{l}-0.190 * * * \\
(-3.30)\end{array}$ & & \\
\hline \multicolumn{7}{|l|}{ Panel B: ID_AFF } \\
\hline$I D \_A F F$ & H1 & - & $\begin{array}{l}-0.003 \\
(-0.56)\end{array}$ & $\begin{array}{l}0.264 * * * \\
(2.69)\end{array}$ & $\begin{array}{l}-0.011 \\
(-1.27)\end{array}$ & $\begin{array}{l}0.284 * * * \\
(2.62)\end{array}$ \\
\hline$D U M \_D I F F$ & & + & & $\begin{array}{l}0.196^{* * * *} \\
(3.13)\end{array}$ & & \\
\hline$I D \_A F F^{*} D U M \_D I F F$ & $\mathrm{H} 2$ & - & & $\begin{array}{l}-0.270 * * * \\
(-2.74)\end{array}$ & & \\
\hline \multicolumn{7}{|l|}{ Panel C:ID_COUNT } \\
\hline$I D \_A F F$ & H1 & - & $\begin{array}{l}-0.001 \\
(-0.70)\end{array}$ & $\begin{array}{l}0.149 * * * \\
(2.83)\end{array}$ & $\begin{array}{l}-0.002 \\
(-1.19)\end{array}$ & $\begin{array}{l}0.172 * * * \\
(2.80)\end{array}$ \\
\hline$D U M \_D I F F$ & & + & & $\begin{array}{l}0.164 * * * \\
(2.69)\end{array}$ & & \\
\hline$I D \_A F F^{*} D U M \_D I F F$ & $\mathrm{H} 2$ & - & & $\begin{array}{l}-0.150 * * * \\
(-2.85)\end{array}$ & & \\
\hline \multicolumn{3}{|l|}{$\mathrm{N}$} & 345 & 345 & 186 & 159 \\
\hline \multicolumn{7}{|c|}{$\begin{array}{l}\text { Notes: The adjusted } \mathrm{R}^{2} \text { of all models in Table } 3 \text { are larger than } 0.44 \text {. The control variables, the industry dummy, and the year } \\
\text { dummy are included in all of the models. *, **, and } * * * \text { indicate statistical significance at the } 10 \text { percent, } 5 \text { percent, and } 1 \\
\text { percent levels in a two-tailed test, respectively. Variables are defined in Appendix A. All test statistics and significance levels } \\
\text { are calculated on the basis of robust standard errors adjusted for heteroskedasticity at the firm and year levels. }\end{array}$} \\
\hline
\end{tabular}

As shown in Table 4, we use $P B R$ as a dependent variable instead of TOBINQ. Other researchers (e.g. Brown \& Perry, 1995) use $P B R$ to measure firm value because of its similarity to TOBINQ in the calculation method. Thus, we perform regression analyses to provide construct validity for TOBINQ. The results are consistent with those in Table 2. In sum, the results in Table 2 remain unchanged after we perform regression analysis using PBR. 
Table 4: Multiple Regressions Of PBR On INTL_DIV

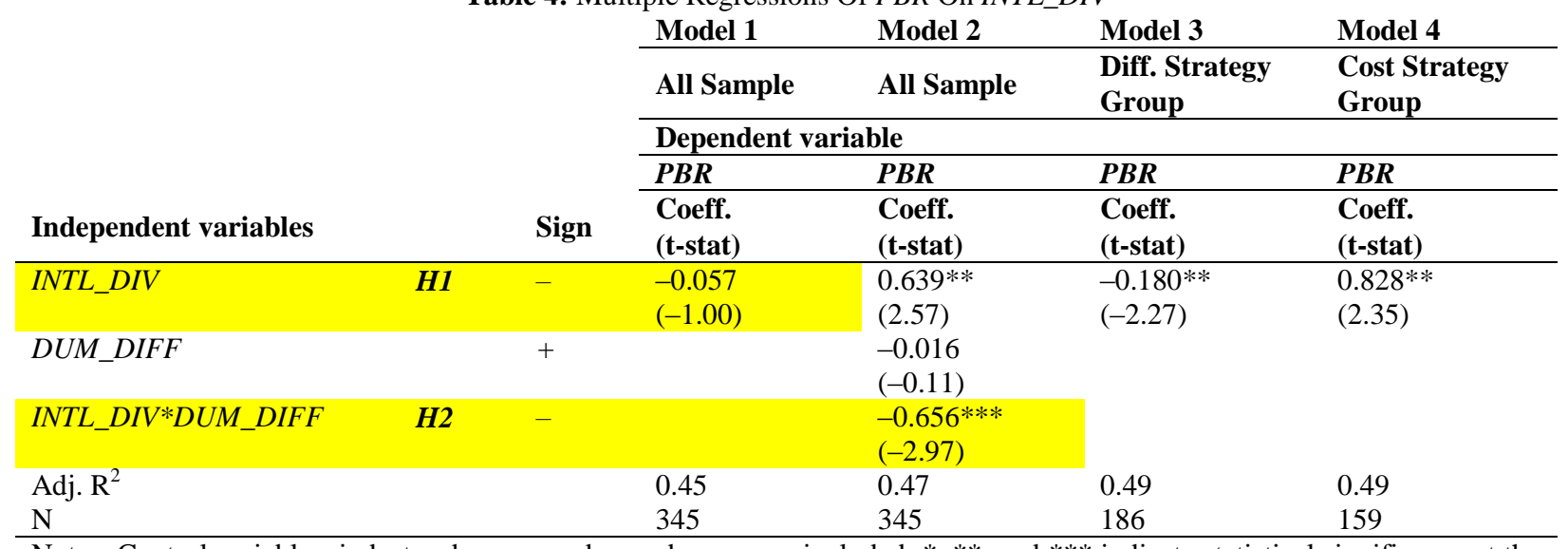

Notes: Control variables, industry dummy, and year dummy are included. *,**, and *** indicate statistical significance at the 10 percent, 5 percent, and 1 percent levels in a two-tailed test, respectively. Variables are defined in Appendix A. All test statistics and significance levels are calculated on the basis of robust standard errors adjusted for heteroskedasticity at the firm and year levels

\section{SUMMARY AND CONCLUSION}

In past studies, researchers were primarily concerned with the direct relationship between ID and performance measured using ROA or ROE. However, these ratios are often used as a short-term accounting performance measure. They also primarily focus on the benefits and costs of ID. Thus, in this study, we primarily examine whether MNCs' product strategy moderates the relationship between ID and firm value as measured using Tobin's Q because Tobin's Q is a more appropriate long-term performance measure. This study is based on the concept of "fit" that is central in the field of strategic management and an important construct for firm success (Naman \& Slevin, 1993).

The result of this study presents the concept that MNCs' product strategy moderates the relationship between ID and firm value as measured using Tobin's Q. Specifically, a positive relationship exists between the two variables for firms pursuing a cost leadership strategy, whereas a negative relationship exists between the two variables for firms pursuing a differentiation strategy. This finding implies that the " $f i t$ " between the cost leadership strategy and Korean MNCs' ID is likely to positively affect the performance of ID. The result supports the contention that the "fit" between strategies or between a strategy and the environmental context in which the strategy is implemented is more likely to achieve superior performance (Miles \& Snow, 1984; Slater \& Olson, 2000; Zajac et al., 2000).

This study has some limitations that should not be ignored. This study uses a measure of product strategy based on R\&D and advertisement intensity. Although we follow prior studies' theoretical and methodological background, this measurement method may be limited in fully reflecting the strategic position of each company. Thus, other methodologies may possibly be used to classify product strategy in a future study. As well, because we use firm-level data in Korean manufacturing industries, this result should be applied cautiously to other industries or countries.

Despite these limitations, our study provides implications for managers and researchers. First, for managers, this empirical evidence on the moderating effect of product strategy on the relationship between ID and firm value offers insights that enable a manager to reconsider the importance of strategic fit when implementing an ID strategy to enhance firm value. Second, this study suggests that researchers should consider this moderating variable (product strategy) related to R\&D and advertisement intensity when studying the relationship between ID and firm value.

In conclusion, this paper adds to the prior literature in that it is the first to shed light on the moderating effect of product strategy on the relationship between ID and firm value on the basis of the strategic fit perspective. 


\section{AUTHORS' INFORMATION}

Donseung Choi, Ph.D candidate and lecturer of Business Administration (BA) has been majoring the BA (International Business) to achieve doctor degree at Sogang University since 2011. Donseung, Choi, School of Business, Sogang University, 35 Baekbumro Mapogu, Seoul, Korea, 121-742. E-mail: dschoi@ sogang.ac.kr.

Eunho Cho, Ph.D candidate and instructor of Business Administration (BA) has been teaching at Sogang University since 2012 and Korea Banking Institution since 2003, respectively. He has been majoring the BA (Accounting) to achieve doctor degree at Sogang University since 2010. He achieved the certificate of CFA, AICPA and FRM which are conferred by US based institutions. Eunho Cho, School of Business, Sogang University, 35 Baekbumro Mapogu, Seoul, Korea, 121-742. E-mail: anselm@ @ogang.ac.kr (Corresponding author).

\section{REFERENCES}

1. Akpinar, A., Jiang, Y., Gómez-Mejía, L. R., Berrone, P., \& Walls, J. L. (2008). Strategic use of CSR as a signal for good management. Ann Arbor, 1001, 48109.

2. Allen, L., \& Pantzalis, C. (1996). Valuation of the operating flexibility of multinational corporations. Journal of International Business Studies, 633-653.

3. $\quad$ Andrews, K. R. (1980). The concept of corporate strategy. New York: Richard D. Irwin.

4. Barney, J. (1991). Firm resources and sustained competitive advantage. Journal of Management, 17(1), 99120.

5. Berger, P. G., \& Ofek, E. (1995). Diversification's effect on firm value. Journal of Financial Economics, 37, 39-65.

6. Black, B. S., Jang, H., \& Kim, W. (2006). Does corporate governance predict firms' market values? Evidence from Korea. Journal of Law, Economics, and Organization, 22(2), 366-413.

7. Brown, B., \& Perry, S. (1995). Halo-removed residuals of fortune's responsibility to the community and environment- A decade of data. Business \& Society, 34(2), 199-215.

8. Caves, R. E. (1996). Multinational enterprise and economic analysis 2 nd ed. Cambridge: Cambridge University Press.

9. Choi, J.-S., Kwak, Y.-M., \& Choe, C. (2010). Corporate social responsibility and corporate financial performance: Evidence from Korea. Australian Journal of Management, 35(3), 291-311.

10. Chung, K. H., \& Pruitt, S. W. (1994). A simple approximation of Tobin's q. Financial Management, 70-74.

11. De, S. (1992). Diversification patterns and long-term corporate performance. Managerial and Decision Economics, 13(1), 1-13.

12. Demsetz, H., \& Lehn, K. (1985). The structure of corporate ownership: Causes and consequences. The Journal of Political Economy, 1155-1177.

13. Denis, D. J., Denis, D. K., \& Yost, K. (2002). Global diversification, industrial diversification, and firm value. The journal of Finance, 57(5), 1951-1979.

14. Dos Santos, M. B., Errunza, V. R., \& Miller, D. P. (2008). Does corporate international diversification destroy value? Evidence from cross-border mergers and acquisitions. Journal of Banking \& Finance, 32(12), 2716-2724.

15. Eden, L., Thomas, D. E., \& Olibe, K. O. (2003). Why multinationality matters: Exploring the "L" in the OLI paradigm. Extending the eclectic paradigm in international business: essays in honor of John Dunning, UK: Cheltenham, 31-54.

16. Fauver, L., Houston, J. F., \& Naranjo, A. (2004). Cross-country evidence on the value of corporate industrial and international diversification. Journal of Corporate Finance, 10(5), 729-752. doi: 10.1016/s0929-1199(03)00027-0

17. Garrod, N., \& Rees, W. (1998). International diversification and firm value. Journal of Business Finance \& Accounting, 25(9-10), 1255-1281.

18. Gomes, L., \& Ramaswamy, K. (1999). An empirical examination of the form of the relationship between multinationality and performance. Journal of International Business Studies, 173-187.

19. Hambrick, D. C. (1983). High profit strategies in mature capital goods industries: a contingency approach. Academy of Management Journal, 26(4), 687-707.

20. Helsen, K., Jedidi, K., \& DeSarbo, W. S. (1993). A new approach to country segmentation utilizing 
multinational diffusion patterns. The Journal of Marketing, 60-71.

21. Hitt, M. A., Hoskisson, R. E., \& Kim, H. (1997). International diversification: Effects on innovation and firm performance in product-diversified firms. Academy of Management Journal, 40(4), 767-798.

22. Hull, C. E., \& Rothenberg, S. (2008). Firm performance: the interactions of corporate social performance with innovation and industry differentiation. Strategic Management Journal, 29(7), 781-789.

23. Jensen, M. C. (1986). Agency costs of free cash flow, corporate finance, and takeovers. The American economic review, 323-329.

24. Katsikeas, C. S., Samiee, S., \& Theodosiou, M. (2006). Strategy fit and performance consequences of international marketing standardization. Strategic Management Journal, 27(9), 867-890.

25. Kim, C. (2009). Corporate social responsibility and firm value. Korean Journal of Financial Studies, 38(4), 507-545.

26. Kogut, B. (1985). Designing global strategies: Comparative and competitive value added chains. Sloan Management Review, 26(4).

27. Kook, C., \& Kang, Y. (2011). Corporate social responsibility, corporate governance, and firm value. Korean Journal of Financial Studies, 40(5), 713-748.

28. Lewellen, W. G. (1971). A pure financial rationale for the conglomerate merger. The journal of Finance, 26(2), 521-537.

29. Lien, Y.-C., \& Li, S. (2013). Does diversification add firm value in emerging economies? Effect of corporate governance. Journal of Business Research, 66(12), 2425-2430. doi:

10.1016/j.jbusres.2013.05.030

30. Lindenberg, E. B., \& Ross, S. A. (1981). Tobin's q ratio and industrial organization. Journal of Business, 132.

31. Lu, J. W., \& Beamish, P. W. (2004). International diversification and firm performance: The S-curve hypothesis. Academy of Management Journal, 47(4), 598-609.

32. McWilliams, A., \& Siegel, D. (2000). Corporate social responsibility and financial performance: Correlation or misspecification? Strategic Management Journal, 21(5), 603-609.

33. Meyer, M., Milgrom, P., \& Roberts, J. (1992). Organizational prospects, influence costs, and ownership changes. Journal of Economics \& Management Strategy, 1(1), 9-35.

34. Miles, R. E., \& Snow, C. C. (1984). Fit, failure and the hall of fame. California Management Review, 26(3), $10-28$.

35. Mizik, N., \& Jacobson, R. (2003). Trading off between value creation and value appropriation: The financial implications of shifts in strategic emphasis. Journal of Marketing, 67(1), 63-76.

36. Myerson, R. B. (1982). Optimal coordination mechanisms in generalized principal-agent problems. Journal of Mathematical Economics, 10(1), 67-81.

37. Naman, J. L., \& Slevin, D. P. (1993). Entrepreneurship and the concept of fit: a model and empirical tests. Strategic Management Journal, 14(2), 137-153.

38. Porter, M. E. (1980). Competitive strategies. New York: The Free Press.

39. Porter, M. E. (1996). What is strategy? Boston: Harvard Business School Press.

40. Prahalad, C., \& Hamel, G. (1990). The core competence of the corporation. Boston (MA), 235-256.

41. Rajan, R., Servaes, H., \& Zingales, L. (2000). The cost of diversity: The diversification discount and inefficient investment. The journal of Finance, 55(1), 35-80.

42. Rugman, A. M. (1979). International diversification and the multinational enterprise. Lxington: Lxington, MA.

43. Saudagaran, S. M. (2002). A review of the literature on the market valuation of multinational firms. Managerial Finance, 28(3), 5-18.

44. Shin, H.-H., \& Stulz, R. M. (1998). Are internal capital markets efficient? Quarterly Journal of Economics, 531-552.

45. Slater, S. F., \& Olson, E. M. (2000). Strategy type and performance: the influence of sales force management. Strategic Management Journal, 21(8), 813-829.

46. Strike, V. M., Gao, J., \& Bansal, P. (2006). Being good while being bad: Social responsibility and the international diversification of US firms. Journal of International Business Studies, 37(6), 850-862.

47. Stulz, R. (1990). Managerial discretion and optimal financing policies. Journal of Financial Economics, 26(1), 3-27.

48. Takeuchi, H., \& Porter, M. E. (1986). Three roles of international marketing in global strategy. Competition 
in global industries, 111-146.

49. Tallman, S., \& Li, J. (1996). Effects of international diversity and product diversity on the performance of multinational firms. Academy of Management Journal, 39(1), 179-196.

50. Waldron, D. G. (2006). International Diversification And The Cost Of Capital: Is More Necessarily Better? International Business \& Economics Research Journal, 5(12), 23-38.

51. Zajac, E. J., Kraatz, M. S., \& Bresser, R. K. (2000). Modeling the dynamics of strategic fit: A normative approach to strategic change. Strategic Management Journal, 21(4), 429-453.

\section{Appendix A}

Variable Definitions

\begin{tabular}{|c|c|}
\hline Variable & Definition \\
\hline \multicolumn{2}{|l|}{ Dependent Variables } \\
\hline$T O B I N Q$ & $\begin{array}{l}\text { (market value of common and preferred stock }+ \text { (current liabilities }- \text { current assets })+ \text { long term } \\
\text { debts)) / book value of total assets. }\end{array}$ \\
\hline \multicolumn{2}{|l|}{ Variable of Interest } \\
\hline$I N T L \_D I V$ & standardized score combining three indicators using factor analysis; $;^{1)}$ \\
\hline$D U M \_D I F F$ & $\begin{array}{l}\text { dummy variable that equals } 1 \text { if firms pursue a differentiation strategy measured based on R\&D } \\
\text { and advertisement following the methodology of Hambrick (1983), and } 0 \text { otherwise; and. }\end{array}$ \\
\hline$I N T L \_D I V * D U M \_D I F F$ & interaction term, measured as $I N T L \_D I V \times D U M \_D I F F$. \\
\hline \multicolumn{2}{|l|}{ Control Variables } \\
\hline SIZE & natural log of total asset; \\
\hline GROWTH & average sales growth rate for past three years; \\
\hline LEVERAGE & total liability / total assets; \\
\hline PROFIT & EBITDA / total assets; \\
\hline RISK & standard deviation of the prior five years EBITDA / total assets; ${ }^{2)}$ and, \\
\hline FIRM AGE & natural $\log$ of $(1+$ the number of years since the firm's establishment $)$. \\
\hline \multicolumn{2}{|c|}{ Variables in Robustness or Additional Tests } \\
\hline$I D \_E X P O R T$ & export portion of net sales, standardized value of (export amount / net sales); \\
\hline$I D \_A F F$ & number of subsidiaries, standardized value of number of subsidiaries held by firms at year-end; \\
\hline ID_COUNT & total liability / total assets; and, \\
\hline$P B R$ & market value of equity / book value of equity. \\
\hline $\begin{array}{l}\text { Three indicators consist } \\
\text { number of foreign subsidi } \\
\text { stands for earnings before }\end{array}$ & $\begin{array}{l}\text { Foreign market penetration (export amount / total sales amount) and foreign market presence (the } \\
\text { s held by firms and the total number of countries in which affiliates are located). }{ }^{2)} \text { EBITDA } \\
\text { erests, taxes, depreciation, and amortization. }\end{array}$ \\
\hline
\end{tabular}

